\title{
Working
}

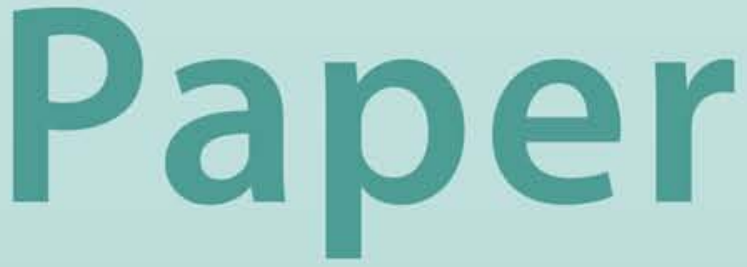


Taxation Reforms and Changes in Revenue Assignments in China

\author{
Ehtisham Ahmad, Raju Singh, and \\ Benjamin Lockwood
}




\title{
IMF Working Paper
}

Fiscal Affairs Department

\section{Taxation Reforms and Changes in Revenue Assignments in China}

\author{
Prepared by Ehtisham Ahmad, Raju Singh, and \\ Benjamin Lockwood ${ }^{1}$
}

July 2004

\begin{abstract}
This Working Paper should not be reported as representing the views of the IMF. The views expressed in this Working Paper are those of the author(s) and do not necessarily represent those of the IMF or IMF policy. Working Papers describe research in progress by the author(s) and are published to elicit comments and to further debate.

The value-added tax (VAT) in China has the unusual feature that capital goods are included in the VAT base. In addition, most services are subject to the business tax, which is not creditable against VAT, but which accrues to local governments, and operates as a turnover tax. On grounds of economic efficiency, it would be desirable to eliminate these distortions so that domestic producers are not increasingly placed at a disadvantage as China dismantles tariff and nontariff barriers on competing goods. Reforming indirect taxation would however generate considerable revenue losses for local governments and, in the absence of any compensatory mechanisms, there would be significant impediments to the needed reforms. This paper focuses on the extent of revenue losses, their distribution across provinces, and possible options for compensation.
\end{abstract}

JEL Classification Numbers: H20, H71, H77

Keywords: Fiscal Policy, Indirect Taxation, Intergovernmental Fiscal Relations, China

Author’s E-Mail Address: eahmad@imf.org; rsingh2@imf.org; b.lockwood@warwick.ac.uk

\footnotetext{
${ }^{1}$ Ehtisham Ahmad and Raju Singh are Division Chief and Senior Economist, respectively, in the Fiscal Affairs Department, and Benjamin Lockwood is Professor of Economics at Warwick University. This paper forms part of a larger project, which also included Professor Mario Fortuna (Azores).
} 


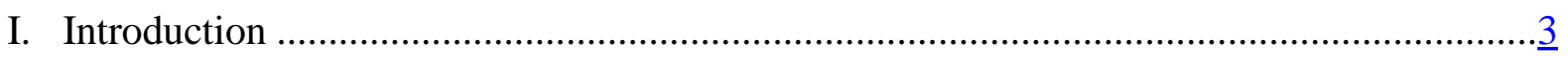

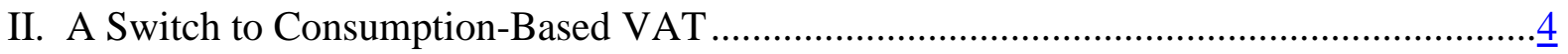

III. Extension of the VAT to Services …........................................................................

IV. The Revenue-Returned System ........................................................................ 14

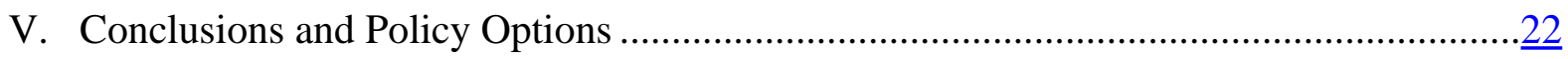

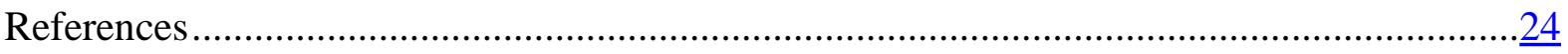

\section{Tables}

1. C-VAT Reform Base Scenario .............................................................................

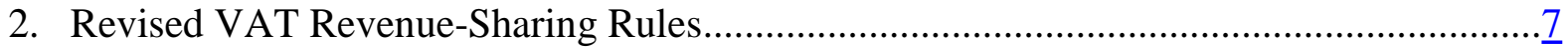

3. C-VAT Reform, Revised Sharing Rule Scenario ........................................................ $\underline{9}$

4. Revised Standard Rate of VAT..........................................................................10

5. Extension of VAT to Services, Base Scenario........................................................... $\frac{12}{12}$

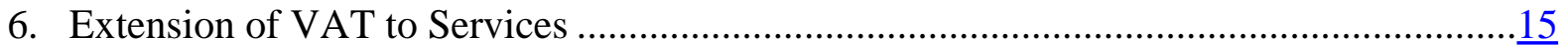

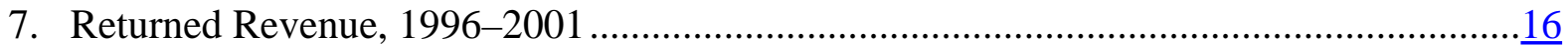

8. Incremental Tax Shares by Region, 2001 ...............................................................18

9. The "Half-Life" of the Revenue-Returned Formula .....................................................19

10. C-VAT Reform Base Scenario Allowing for Revenue-Returned...................................21

Figures

1. Provincial Percentage Revenue Losses from C-VAT Reform ........................................ 7

2. Provincial Losses from Extension of VAT to Services ............................................... 13

3. Incremental VAT Shares by Province .....................................................................19

4. Provincial Revenue Losses from C-VAT Reform ....................................................... 


\section{INTRODUCTION}

In 1994, China carried a far-reaching set of fiscal reforms. On the revenue side, it assigned some revenues entirely to the central or local governments and introduced sharing of revenues for taxes such as the value-added tax (VAT). Thus, 75 percent of the VAT revenue was to be assigned to the central government, while the remaining 25 percent of the VAT, as well as the business tax, were assigned to local governments. ${ }^{2}$

At the same time, the system of transfers from the center to local governments was redesigned to include an equalization component based on the expenditure needs of each province and revenue capacities. However, in order to convince the richer provinces to accept the new design, a "revenue-returned mechanism" was introduced, to transfer back 30 percent of the increase in VAT and excise tax revenue to the originating province.

The VAT in China has the unusual feature that capital goods are included in the VAT base, so that the VAT is a production-based (P-VAT), rather than forming a more traditional consumption-based VAT (C-VAT). A second notable feature of indirect taxation in China is that most services are subject to a turnover tax, known as the business tax, which is not creditable against VAT, but which accrues to local governments. These features lead to several forms of cascading, distorting the choice of inputs for the production of both goods and services and leading to an arbitrary (and unknown) pattern of effective tax rates on different consumption items. On the grounds of economic efficiency, it would be desirable to eliminate these distortions.

Furthermore, China's entry into the World Trade Organization (WTO) has placed increased urgency on the need to reform the country's indirect taxation. The current VAT system will increasingly place domestic producers at a disadvantage as the country complies with WTO requirements and dismantles tariff and nontariff barriers on competing goods. The situation is further complicated, as the tax administration only refunds a part of the paid VAT to Chinese exporters.

Moving to a C-VAT is a critical reform, but would imply an overall revenue loss, as the exclusion of capital goods reduces the tax base. An extension of the VAT to services would also imply a revenue loss for local governments that could be offset by the revenue gain at the center. The paper also shows that the magnitude of these revenue losses, both absolutely, and relative to current VAT revenues, will vary across provinces. Thus the reforms will not be easy to implement, unless provinces are compensated for the compounded revenue shortfall they will face.

This paper focuses in particular on the extent of revenue losses, their distribution across provinces, and possible options for compensation. We present numerical simulations of the

\footnotetext{
${ }^{2}$ See Ahmad, Qiang, and Tanzi (1995).
} 
redistribution of tax revenue between individual provinces, and between provinces as a whole and the center. In order to make this reform a viable option, the system of transfers will need to be simultaneously reformed. ${ }^{3}$

\section{A SWITCH To CONSUMPTION-BASED VAT}

This section investigates the revenue implications of a switch from the current P-VAT to a CVAT for the center and local governments, as well as across local governments. ${ }^{4}$ Simple simulations have been run on the basis of 2001 data. Any effect of the tax reforms on the size of the relevant tax bases (so-called behavioral responses) have been excluded. Only the "first-round" effects of these reforms are reported, and the issue of "revenue-returned" is not addressed at this stage.

The revenue raised by VAT is defined as the tax base $\mathrm{x}$ tax rate $\mathrm{x}$ collection efficiency. The simulations presented here illustrate the revenue effects from a change in the VAT tax base implied by the reform. A standard VAT rate of 17 percent is assumed here to apply to changes in the base. For the collection efficiency, an upper bound of 100 percent and a lower bound of 50 percent are assumed. This parameter measures not only tax evasion by enterprises, or failure by the tax administration to collect tax due, but also the application of the lower (13 percent) rate of VAT to some sectors, and lower rates of VAT, or even exemption, for smaller enterprises.

\section{Base scenario}

The first step is to construct an estimate of purchases of capital inputs by taxable enterprises. In principle, under a C-VAT, VAT on purchases of all capital inputs, including buildings, should be creditable. However, in China, construction as a service is taxed under the business tax. So, for VAT purposes, it is a VAT-exempt sector, and the VAT paid on building materials embedded in buildings would not be creditable. Thus, the current simulations focus only on the impact of allowing VAT credits of machinery and equipment (M\&E). This will in general produce an underestimate of the losses in tax revenue to provinces, but will approximate the relative losses across provinces (i.e., the changes in horizontal imbalances) due to this possible reform. Table 1 presents the result of these calculations.

The first two columns give the value of output of the sectors of the provincial economies liable for VAT, based on China's national income accounts classification. These include secondary industry excluding construction, and commerce (wholesale, retail, and catering). ${ }^{5}$

\footnotetext{
${ }^{3}$ Ahmad, Singh, and Fortuna (2004).

${ }^{4}$ The simulations presented here use available published data from the China Statistical Yearbook.

5 This is based on the fact that the exempt sectors comprise the primary sector (agriculture), the construction sector, and all services, and government sectors except for commerce.
} 
Table 1. C-VAT Reform, Base Scenario

(In billions of yuan)

\begin{tabular}{|c|c|c|c|c|c|c|c|c|}
\hline Province & $\begin{array}{c}2001 \\
\text { Value of } \\
\text { Wholesale, Retail } \\
\text { and Catering } \\
\text { Trade }\end{array}$ & $\begin{array}{l}\text { Value of } \\
\text { Secondary } \\
\text { Industry } \\
\text { (excluding } \\
\text { construction) }\end{array}$ & $\begin{array}{l}\text { Calculated } \\
\text { Purchases of } \\
\text { M\&E }\end{array}$ & $\begin{array}{c}\text { Loss of VAT } \\
\text { Revenue } \\
\text { (100 percent CE) }\end{array}$ & $\begin{array}{l}\text { Loss of VAT } \\
\text { Revenue } \\
\text { (50 percent CE) }\end{array}$ & $\begin{array}{c}2001 \\
\text { VAT } \\
\text { Revenue }\end{array}$ & $\begin{array}{l}\text { Revenue Loss as } \\
\text { Percent of Current } \\
\text { VAT Revenue } \\
\text { (100 percent CE) }\end{array}$ & $\begin{array}{c}\text { Revenue Loss as } \\
\text { Percent of } \\
\text { Current VAT } \\
\text { Revenue } \\
\text { (50 percent CE) }\end{array}$ \\
\hline Beijing & 23.78 & 81.62 & 19.03 & 0.81 & 0.40 & 5.90 & 13.71 & 6.85 \\
\hline Tianjin & 17.83 & 82.12 & 18.64 & 0.79 & 0.40 & 3.49 & 22.72 & 11.35 \\
\hline Hebei & 50.17 & 243.96 & 55.15 & 2.34 & 1.17 & 4.88 & 47.98 & 23.99 \\
\hline Shanxi & 14.60 & 77.98 & 17.51 & 0.74 & 0.37 & 3.09 & 24.11 & 12.05 \\
\hline Inner Mongolia & 14.82 & 50.67 & 11.82 & 0.50 & 0.25 & 1.48 & 33.85 & 16.92 \\
\hline Liaoning & 69.65 & 219.01 & 51.55 & 2.19 & 1.10 & 6.65 & 32.94 & 16.47 \\
\hline Jilin & 26.74 & 72.47 & 17.37 & 0.74 & 0.37 & 2.42 & 30.49 & 15.24 \\
\hline Heilongjiang & 35.02 & 176.78 & 39.85 & 1.69 & 0.85 & 5.26 & 32.23 & 16.11 \\
\hline Shanghai & 55.04 & 212.12 & 48.90 & 2.08 & 1.04 & 11.20 & 18.56 & 9.28 \\
\hline Jiangsu & 95.51 & 427.09 & 97.19 & 4.13 & 2.07 & 13.20 & 31.29 & 15.64 \\
\hline Zhejiang & 90.88 & 310.63 & 72.46 & 3.08 & 1.54 & 10.24 & 30.07 & 15.03 \\
\hline Anhui & 34.08 & 119.16 & 27.73 & 1.18 & 0.59 & 2.83 & 41.68 & 20.84 \\
\hline Fujian & 41.15 & 164.53 & 37.80 & 1.61 & 0.80 & 4.08 & 39.40 & 19.70 \\
\hline Jiangxi & 19.21 & 59.56 & 14.04 & 0.60 & 0.30 & 1.72 & 34.63 & 17.31 \\
\hline Shandong & 89.13 & 409.22 & 92.93 & 3.95 & 1.97 & 10.03 & 39.38 & 19.68 \\
\hline Henan & 42.21 & 227.99 & 51.15 & 2.17 & 1.09 & 4.44 & 49.01 & 24.50 \\
\hline Hubei & 47.34 & 206.65 & 47.12 & 2.00 & 1.00 & 3.71 & 53.93 & 26.96 \\
\hline Hunan & 38.24 & 130.95 & 30.54 & 1.30 & 0.65 & 2.94 & 44.18 & 22.09 \\
\hline Guangdong & 104.44 & 473.24 & 107.58 & 4.57 & 2.29 & 17.25 & 26.51 & 13.25 \\
\hline Guangxi & 29.52 & 64.82 & 16.00 & 0.68 & 0.34 & 2.39 & 28.49 & 14.24 \\
\hline Hainan & 7.26 & 7.16 & 2.10 & 0.09 & 0.04 & 0.35 & 25.35 & 12.67 \\
\hline Chongqing & 16.78 & 57.66 & 13.44 & 0.57 & 0.29 & 1.78 & 32.17 & 16.08 \\
\hline Sichuan & 47.48 & 140.78 & 33.36 & 1.42 & 0.71 & 3.80 & 37.31 & 18.65 \\
\hline Guizhou & 8.41 & 33.50 & 7.70 & 0.33 & 0.16 & 1.43 & 22.94 & 11.47 \\
\hline Yunnan & 20.22 & 72.40 & 16.81 & 0.71 & 0.36 & 3.36 & 21.25 & 10.62 \\
\hline Tibet & 1.66 & 1.08 & 0.36 & 0.02 & 0.01 & 0.08 & 18.23 & 9.11 \\
\hline Shaanxi & 12.47 & 60.61 & 13.70 & 0.58 & 0.29 & 2.33 & 24.96 & 12.48 \\
\hline Gansu & 12.30 & 35.65 & 8.47 & 0.36 & 0.18 & 1.34 & 26.92 & 13.46 \\
\hline Qinghai & 2.31 & 8.92 & 2.06 & 0.09 & 0.04 & 0.39 & 22.69 & 11.34 \\
\hline Ningxia & 2.35 & 10.22 & 2.33 & 0.10 & 0.05 & 0.39 & 25.71 & 12.85 \\
\hline Xinjiang & 12.82 & 45.00 & 10.47 & 0.44 & 0.22 & 1.74 & 25.59 & 12.79 \\
\hline Totals & & & & 41.87 & 20.94 & 134.17 & & \\
\hline Averages & & & & & & & 30.91 & 15.45 \\
\hline
\end{tabular}

Sources: China Statistical Yearbook, authors’ calculations. 
Next, using the relevant coefficients from the latest available (1997) input-output table, we construct an estimate of the purchases of M\&E by taxable sectors in each province. These estimates are reported in the third column of the table. ${ }^{6}$

The revenue shortfall implied by a move to a C-VAT for each province can now be calculated. The results are presented in the fourth and fifth columns of Table 1: (i) given the current rate of VAT of 17 percent on purchases of M\&E; (ii) assuming that the existing revenue-sharing rule of 25 percent of VAT revenue-returned to the provinces is in place; and (iii) ignoring the operation of the revenue-returned formula. The results expressed as percentages of the current VAT revenue received by provinces in 2001 are given in the sixth and seventh columns.

There is considerable variation of percentage losses across provinces, as indicated by a coefficient of variation of about 0.31 . The cause of this variation stems from the different extent to which the provinces rely on secondary industry; the more important this is for a province, the more it stands to lose from this reform. In the case of 100 percent efficiency in revenue collection, the average loss across provinces is about 30 percent, with some peaks (e.g., 54 percent of revenue from the VAT in Hebei). For a lower collection efficiency, the average loss across provinces drops by half, with the loss below 10 percent of current VAT revenue for Beijing, Shanghai, and Tibet, where manufacturing is relatively unimportant. Are poorer provinces more affected by a move to a C-VAT? The scatter diagram presented in Figure 1 suggests a rough inverted "U” shape relationship between regional GDP per capita and the percentage in revenue loss. Both lower-income provinces (as they rely more on agriculture) and higher-income provinces (such as Beijing and Shanghai, which rely more on services) would seem to lose less than middle-income provinces. ${ }^{7}$

What would be the effect on the finances of the central government? Our estimate of the reduction in central government's 75 percent share of VAT revenue implied by the move to the C-VAT is between Y 62.8 billion and Y 125.6 billion, depending on what is assumed about collection efficiency. For comparison, in 2001, total VAT revenue was about Y 536 billion, of which central government's share was Y 402 billion.

\footnotetext{
${ }^{6}$ In the 1997 input-output table, input-output coefficients are reported for all the components of secondary industry separately (mining and quarrying, foodstuffs, textiles, other manufacturing, electric power steam and hot water, gas and petroleum, chemicals, building materials and non-metal products, metal products, and machinery and equipment). We calculate the unweighted average of these coefficients, and then apply this average to the figure for secondary industry minus construction. Note that provincial input-output tables were not available and there may be differences in the coefficients across provinces. Thus, the estimates above should be seen as rough approximations, or illustrations of method.

${ }^{7}$ Figure 1 shows the more realistic case of 50 percent collection efficiency, but the picture is similar in the other polar case of 100 percent collection efficiency. Note also that three outlying provinces are responsible for the inverted U-shape. If these provinces are excluded, the richer provinces would be seen to lose more than the poorer ones.
} 
Figure 1. Provincial Percentage Revenue Losses from C-VAT Reform, Base Scenario

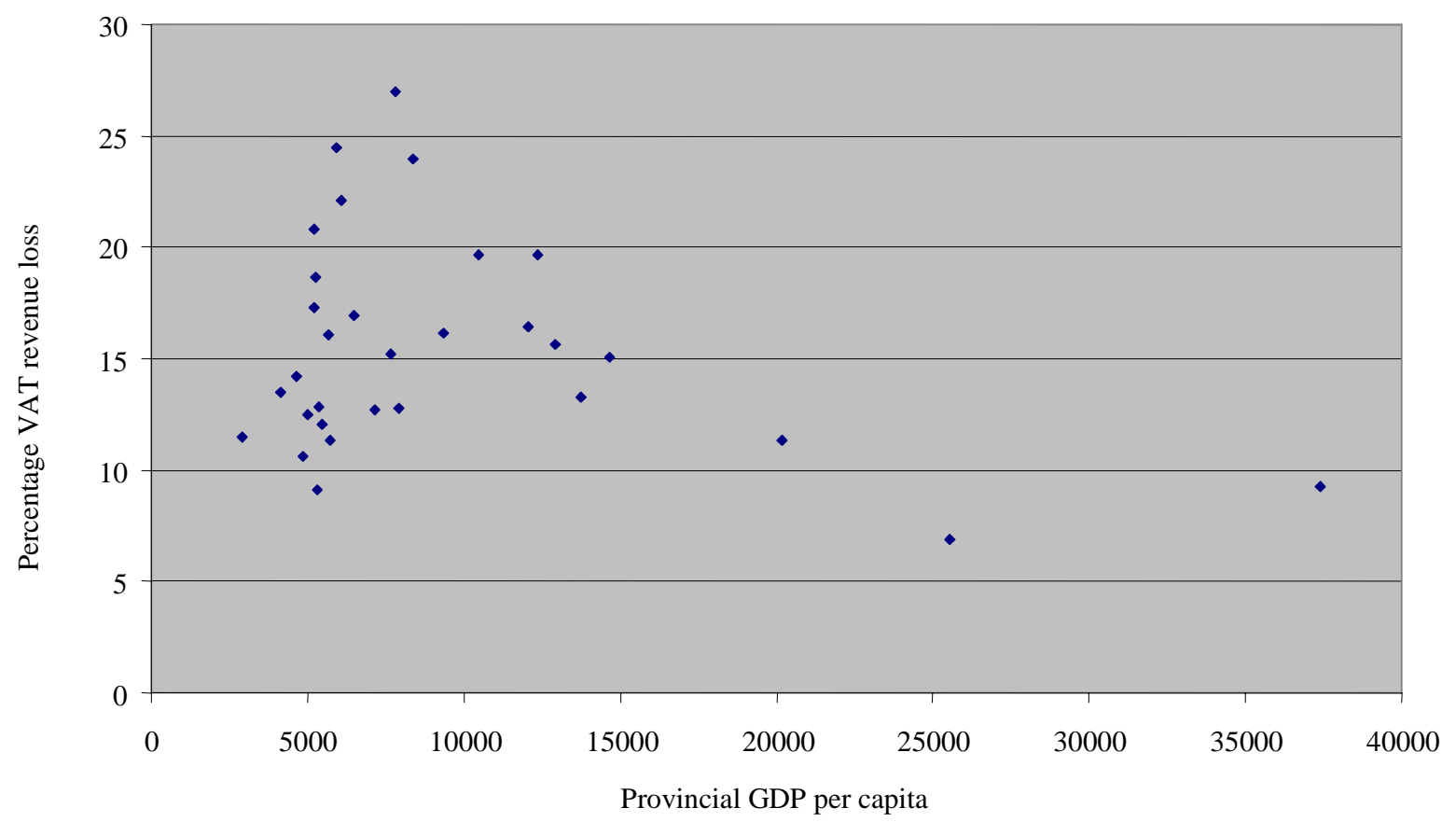

Sources: China Statistical Yearbook; and authors’ calculations.

\section{Revised sharing rule scenario}

One possible option to compensate provinces for their revenue shortfall would be to increase the share of VAT revenue assigned to local governments. In this case, the share of revenuereturned to the provinces increased from the current 25 percent up to the point where the aggregate provincial VAT returns to its initial level (i.e., revenue-neutrality for provinces only). The first step is to calculate the increase in the VAT share required to achieve this objective. This is shown in the first column of Table 2 below.

Table 2. Revised VAT Revenue-Sharing Rules

Revenue-Neutral VAT

Share for Provinces

(In percent)
Revenue Loss of Central

Government

(In billions of yuan)
Revenue Loss of Central

Government as Percent of 2001 VAT Revenue

Low collection efficiency

29.6

36.3
114.17

142.67
28.4

35.5

High collection efficiency

(100 percent)

Source: Authors' calculations. 
The increase in the provincial VAT sharing rate needed for overall revenue-neutrality would depend on the efficiency in the VAT collection. ${ }^{8}$ However, the difference would not seem to be large. At the lower bound of 50 percent efficiency, the sharing rate would need to rise to 29.6 percent from the current 25 percent, while at the upper bound of 100 percent efficiency, the rate would need to rise to 36.3 percent.

However, as Table 2 indicates, the budgetary consequences for central government of this option are quite severe, as it must share a larger proportion of a smaller pool of VAT revenue with provincial governments. For both levels of collection efficiency considered in this exercise, the central government would lose about one-third of its current VAT revenue if it fully compensated the provinces for the reform.

Given these revised sharing rates, one can then calculate the change in revenue on a province-by-province basis given the switch to the C-VAT and the offsetting rate rise. These changes are shown in Table 3 below. As might be expected, less industrialized provinces gain (i.e., which rely more either on agriculture or services), whereas those where secondary industry is important lose most.

Clearly, some poorer provinces such as Tibet and Guizhou gain because of their reliance on agriculture. On the other hand, cities such as Beijing and Shanghai also gain. Overall, the correlation between GDP per capita and gains from the reform is strongly positive (a correlation coefficient of 0.623 in the 50 percent efficiency case, and of 0.548 in the 100 percent efficiency case). Hence, a higher VAT sharing rule would not appropriately target resource-constrained provinces and could result in making the move to C-VAT strongly disequalizing.

\section{Raising the standard rate of VAT}

An alternative option would be to compensate provinces by raising the standard rate of VAT from 17 percent to make the reform revenue-neutral (i.e., to leave aggregate VAT revenue unchanged). If the rate rise is revenue-neutral for the provinces in aggregate, it would also be revenue-neutral for the central government. However, the problem is that quite sharp increases in the standard rate would be needed, as Table 4 shows.

Increasing VAT rates to this extent could have undesirable macroeconomic and incentive effects on the economy, for example by raising prices and decreasing consumption demand. The fact that "second-round" effects are not taken into account in these simulations is a serious limitation, as a sharp increase in the VAT rate would certainly imply changes in behavior, reducing the VAT base significantly in the short run.

\footnotetext{
${ }^{8}$ Generally, the formula is that the new rate (as a fraction), is equal to 0.25 times $134.17 /(134.17-\mathrm{X})$, where $\mathrm{X}$ is the revenue gain/loss in billion of yuan as given in Table 3 , so $\mathrm{X}=20.94$ or 41.87 .
} 
Table 3. C-VAT Reform, Revised Sharing Rule Scenario

(In billions of yuan)

\begin{tabular}{|c|c|c|c|c|c|c|c|}
\hline Province & $\begin{array}{c}\text { Post-Reform } \\
\text { VAT Revenue } \\
\text { with New Sharing } \\
\text { Rule } \\
\text { (50 percent CE) }\end{array}$ & $\begin{array}{l}\text { Post-Reform VAT } \\
\text { Revenue with New } \\
\text { Sharing Rule } \\
\text { (100 percent CE) }\end{array}$ & $\begin{array}{l}\text { Current VAT } \\
\text { Revenue }\end{array}$ & $\begin{array}{l}\text { Net Revenue Gain } \\
\text { (50 percent CE) }\end{array}$ & $\begin{array}{l}\text { Net Revenue Gain } \\
\text { (100 percent CE) }\end{array}$ & $\begin{array}{l}\text { Revenue Gain as } \\
\text { Percent of Current } \\
\text { VAT Revenue } \\
\text { (50 percent CE) }\end{array}$ & $\begin{array}{l}\text { Revenue Gain as } \\
\text { Percent of Current } \\
\text { VAT Revenue } \\
\text { (100 percent CE) }\end{array}$ \\
\hline Beijing & 6.51 & 7.40 & 5.90 & 0.61 & 1.50 & 10.37 & 25.43 \\
\hline Tianjin & 3.66 & 3.92 & 3.49 & 0.18 & 0.43 & 5.03 & 12.34 \\
\hline Hebei & 4.40 & 3.69 & 4.88 & -0.49 & -1.19 & -9.94 & -24.39 \\
\hline Shanxi & 3.22 & 3.41 & 3.09 & 0.13 & 0.32 & 4.21 & 10.32 \\
\hline Inner Mongolia & 1.46 & 1.43 & 1.48 & -0.02 & -0.06 & -1.56 & -3.85 \\
\hline Liaoning & 6.58 & 6.48 & 6.65 & -0.07 & -0.17 & -1.02 & -2.52 \\
\hline Jilin & 2.43 & 2.45 & 2.42 & 0.01 & 0.03 & 0.43 & 1.04 \\
\hline Heilongjiang & 5.22 & 5.18 & 5.26 & -0.03 & -0.08 & -0.60 & -1.49 \\
\hline Shanghai & 12.03 & 13.25 & 11.20 & 0.84 & 2.06 & 7.49 & 18.38 \\
\hline Jiangsu & 13.19 & 13.18 & 13.20 & -0.01 & -0.02 & -0.05 & -0.13 \\
\hline Zhejiang & 10.31 & 10.41 & 10.24 & 0.07 & 0.17 & 0.68 & 1.65 \\
\hline Anhui & 2.65 & 2.40 & 2.83 & -0.18 & -0.43 & -6.20 & -15.23 \\
\hline Fujian & 3.88 & 3.59 & 4.08 & -0.20 & -0.49 & -4.85 & -11.91 \\
\hline Jiangxi & 1.69 & 1.64 & 1.72 & -0.03 & -0.09 & -2.02 & -4.98 \\
\hline Shandong & 9.54 & 8.84 & 10.03 & -0.49 & -1.19 & -4.84 & -11.88 \\
\hline Henan & 3.97 & 3.29 & 4.44 & -0.47 & -1.15 & -10.55 & -25.89 \\
\hline Hubei & 3.21 & 2.49 & 3.71 & -0.50 & -1.23 & -13.46 & -33.03 \\
\hline Hunan & 2.71 & 2.38 & 2.94 & -0.23 & -0.55 & -7.68 & -18.86 \\
\hline Guangdong & 17.73 & 18.43 & 17.25 & 0.48 & 1.18 & 2.79 & 6.83 \\
\hline Guangxi & 2.43 & 2.48 & 2.39 & 0.04 & 0.09 & 1.62 & 3.95 \\
\hline Hainan & 0.36 & 0.38 & 0.35 & 0.01 & 0.03 & 3.47 & 8.52 \\
\hline Chongqing & 1.77 & 1.75 & 1.78 & -0.01 & -0.02 & -0.57 & -1.40 \\
\hline Sichuan & 3.66 & 3.46 & 3.80 & -0.14 & -0.34 & -3.61 & -8.87 \\
\hline Guizhou & 1.50 & 1.60 & 1.43 & 0.07 & 0.17 & 4.90 & 12.01 \\
\hline Yunnan & 3.56 & 3.85 & 3.36 & 0.20 & 0.49 & 5.90 & 14.48 \\
\hline Tibet & 0.09 & 0.10 & 0.08 & 0.01 & 0.02 & 7.69 & 18.87 \\
\hline Shaanxi & 2.42 & 2.55 & 2.33 & 0.09 & 0.21 & 3.70 & 9.08 \\
\hline Gansu & 1.37 & 1.42 & 1.34 & 0.03 & 0.08 & 2.54 & 6.23 \\
\hline Qinghai & 0.40 & 0.43 & 0.39 & 0.02 & 0.05 & 5.05 & 12.38 \\
\hline Ningxia & 0.40 & 0.42 & 0.39 & 0.01 & 0.03 & 3.26 & 7.98 \\
\hline Xinjiang & 1.80 & 1.88 & 1.74 & 0.06 & 0.14 & 3.33 & 8.16 \\
\hline Totals & 134.17 & 134.16 & 134.17 & 0.00 & 0.00 & $\ldots$ & $\ldots$ \\
\hline
\end{tabular}

Sources: China Statistical Yearbook; and authors’ calculations. 
Table 4. Revised Standard Rate of VAT

\begin{tabular}{lccc}
\hline & $\begin{array}{c}\text { Revenue-Neutral } \\
\text { Standard VAT Rate for } \\
\text { Provinces } \\
\text { (In percent) }\end{array}$ & $\begin{array}{c}\text { Revenue Loss of Central } \\
\text { Government } \\
\text { (In billions of yuan) }\end{array}$ & $\begin{array}{c}\text { Revenue Loss of Central } \\
\text { Government as Percent } \\
\text { of 2001 VAT Revenue }\end{array}$ \\
\hline $\begin{array}{l}\text { Low collection efficiency } \\
\text { (50 percent) }\end{array}$ & 20.1 & 0 & 0 \\
$\begin{array}{l}\text { High collection efficiency } \\
\text { (100 percent) }\end{array}$ & 24.7 & 0 & 0 \\
\hline
\end{tabular}

Source: Authors’ calculations.

\section{EXTENSION OF THE VAT TO SERVICES}

The extension of the VAT to services is an important complement of the tax reforms and should largely offset losses associated with the C-VAT. However, since services are already subject to the business tax, the latter would be replaced as part of the reforms. The difficulty is that the business tax accrues entirely to local governments, whereas the VAT would presumably be shared. We estimate the magnitude of these distributional effects.

\section{Base scenario}

We first calculate the addition to the VAT base implied by the taxation of services. For this purpose, we will assume that all services which were previously taxed by the business tax will be subject to VAT, with the exception of finance and insurance. ${ }^{9}$ It is well known that transactions in this sector are hard to tax under a value-added tax, as the share of value-added between borrower and lender is hard to determine. ${ }^{10}$ We also assume that the business tax at the current rate continues to apply to the finance and insurance sector. The results are presented in Column 1 of Table 5. ${ }^{11}$

However, in moving to a VAT on services, there will be a loss of revenue stemming from the removal of cascading. This is, in a sense, the revenue cost of removing the economic distortions associated with cascading, as discussed above. We approximate this revenue loss

\footnotetext{
${ }^{9}$ In 2001, the financial and insurance sectors accounted for 28 percent of the business tax proceeds.

${ }^{10}$ Ebrill, Keen, Bodin, and Summers (2001).

${ }^{11}$ In terms of the Chinese classification of national income, the service sectors added to the VAT base are: services to farming, forestry and fishery, geological prospecting and water conservancy, transport, storage, post and telecommunications services, real estate, other; and one-third of: social services, health care, sports and social welfare; education, culture, arts, radio, film and television; scientific research and polytechnic services.
} 
by calculating the value of purchases by sectors already liable for VAT (in terms of the Chinese classification of national income, these are secondary industry and commerce) from sectors to which VAT is assumed to be extended. The VAT paid on these purchases will now be creditable, and thus these purchases are lost from the VAT base. The results of this calculation are presented in Column 2 of Table 5. The net increase (Column 3) is the difference between the figures in Columns 1 and 2. The next step is to calculate the implied gain in VAT revenue. This is done in Columns 4 and 5 of Table 5, assuming 100 percent and 50 percent collection efficiencies, respectively.

The final step is to compare this to the revenue lost by the provinces from the abolition of the business tax. We have assumed that the business tax would remain for the financial and insurance sectors. The relative size of these sectors differs however widely by region.

In 2001, they provided about 15 percent of provincial GDP in Beijing, but only about 0.9 percent of GDP in Heilongjiang. To calculate how much each province would lose from the abolition of the business tax except on this sector, we assume that the province retains a share of its business tax revenue, where (i) $a_{i}$ is proportional to the share of finance and insurance in regional GDP; and (ii) overall, 28 percent of business tax revenue is retained.

The formula for $\mathrm{a}_{\mathrm{i}}$ can be calculated, ${ }^{12}$ and this allows us to calculate the amount $\left(1-\mathrm{a}_{\mathrm{i}}\right)$ times actual business tax revenue in province $i$, which is the amount presumed to be lost. This is shown by province in Column 6 of Table 5 . The overall gain from this reform is then the increase in VAT revenue (calculated at 100 percent or 50 percent VAT efficiency) minus the calculated loss of revenue from the business tax. This is shown in Columns 7 and 8 of Table 5.

The pattern of gains and losses across provinces is complex, as several factors are at work. First, other things being equal, provinces that have a large service sector, but where finance and insurance is relatively unimportant, will tend to lose most, as they lose all their revenue from the business tax on these activities. By the same token, provinces where finance and insurance is important will tend to lose less or gain, as their business tax revenue from these activities is not lost. Additional insight can be obtained from looking at how (percentage) losses vary across provinces by GDP per capita. This is shown in Figure 2 below.

\footnotetext{
${ }^{12}$ Let $\mathrm{R}_{\mathrm{i}}$ denote the business tax revenue in province $i$. Then (i) states that $\mathrm{a}_{\mathrm{i}}=\lambda \mathrm{s}_{\mathrm{i}}$ for province $\mathrm{i}$, where $\mathrm{s}_{\mathrm{i}}$ is the share of insurance and finance in province $\mathrm{i}$, and (ii) states that $\sum_{i} a_{i} R_{i}=0.28 \sum_{i} R_{i}$. Solving these equations for $\lambda$, and substituting back in relationship (i), we get $a_{i}=0.28 s_{i} / \frac{\sum_{i} s_{i} R_{i}}{\sum_{i} R_{i}}$.
} 
Table 5. Extension of VAT to Services, Base Scenario

(In hundreds of millions of yuan)

\begin{tabular}{|c|c|c|c|c|c|c|c|c|}
\hline Province & \begin{tabular}{l}
\multicolumn{1}{c}{2001} \\
Value-Added in \\
Newly Taxable \\
Service Sectors
\end{tabular} & $\begin{array}{l}\text { } 2001 \\
\text { Total Purchases } \\
\text { from Currently } \\
\text { Exempt Sectors }\end{array}$ & $\begin{array}{l}\text { Net } \\
\text { Increase in } \\
\text { VAT Base }\end{array}$ & $\begin{array}{l}\text { Increase in VAT } \\
\text { Revenue } \\
\text { (100 percent } \\
\text { efficiency) }\end{array}$ & $\begin{array}{c}\text { Increase in VAT } \\
\text { Revenue } \\
\text { (50 percent } \\
\text { efficiency) }\end{array}$ & $\begin{array}{l}2001 \text { Revenue from } \\
\text { Business Tax, } \\
\text { Excluding Finance } \\
\text { and Insurance }\end{array}$ & $\begin{array}{l}\text { Gain from } \\
\text { Reform, } \\
\text { (100 percent } \\
\text { efficiency) }\end{array}$ & $\begin{array}{l}\text { Gain from } \\
\text { Reform } \\
\text { (50 percent } \\
\text { efficiency) }\end{array}$ \\
\hline Beijing & 771.13 & 52.21 & 718.93 & 30.55 & 15.28 & 40.91 & -10.36 & -25.63 \\
\hline Tianjin & 474.31 & 47.67 & 426.64 & 18.13 & 9.07 & 35.60 & -17.47 & -26.53 \\
\hline Hebei & 1136.63 & 139.41 & 997.23 & 42.38 & 21.19 & 42.34 & 0.05 & -21.14 \\
\hline Shanxi & 394.87 & 43.42 & 351.45 & 14.94 & 7.47 & 18.05 & -3.12 & -10.58 \\
\hline Inner & 370.57 & 32.45 & 338.12 & 14.37 & 7.19 & 18.00 & -3.63 & -10.82 \\
\hline \multicolumn{9}{|l|}{ Mongolia } \\
\hline Liaoning & 979.16 & 144.72 & 834.45 & 35.46 & 17.73 & 76.41 & -40.94 & -58.67 \\
\hline Jilin & 420.29 & 50.82 & 369.47 & 15.70 & 7.85 & 26.37 & -10.66 & -18.51 \\
\hline Heilongjiang & 720.85 & 99.96 & 620.88 & 26.39 & 13.19 & 34.59 & -8.20 & -21.40 \\
\hline Shanghai & 1109.98 & 130.29 & 979.69 & 41.64 & 20.82 & 71.58 & -29.95 & -50.76 \\
\hline Jiangsu & 2016.50 & 250.17 & 1766.34 & 75.07 & 37.53 & 83.58 & -8.51 & -46.04 \\
\hline Zhejiang & 1238.00 & 198.97 & 1039.03 & 44.16 & 22.08 & 102.34 & -58.19 & -80.26 \\
\hline Anhui & 657.12 & 75.71 & 581.41 & 24.71 & 12.35 & 27.37 & -2.66 & -15.01 \\
\hline Fujian & 996.54 & 99.84 & 896.70 & 38.11 & 19.05 & 46.89 & -8.78 & -27.83 \\
\hline Jiangxi & 599.04 & 39.56 & 559.48 & 23.78 & 11.89 & 20.95 & 2.82 & -9.07 \\
\hline Shandong & 1902.29 & 237.81 & 1664.48 & 70.74 & 35.37 & 69.86 & 0.88 & -34.49 \\
\hline Henan & 1162.18 & 126.57 & 1035.60 & 44.01 & 22.01 & 46.89 & -2.88 & -24.88 \\
\hline Hubei & 786.18 & 121.94 & 664.24 & 28.23 & 14.12 & 33.54 & -5.31 & -19.42 \\
\hline Hunan & 835.85 & 83.82 & 752.03 & 31.96 & 15.98 & 29.90 & 2.06 & -13.92 \\
\hline Guangdong & 2657.72 & 276.09 & 2381.62 & 101.22 & 50.61 & 263.06 & -161.84 & -212.45 \\
\hline Guangxi & 484.52 & 49.90 & 434.62 & 18.47 & 9.24 & 30.98 & -12.51 & -21.74 \\
\hline Hainan & 121.00 & 8.69 & 112.31 & 4.77 & 2.39 & 8.76 & -3.99 & -6.38 \\
\hline Chongqing & 408.70 & 36.86 & 371.83 & 15.80 & 7.90 & 22.01 & -6.21 & -14.11 \\
\hline Sichuan & 968.82 & 95.18 & 873.64 & 37.13 & 18.56 & 49.59 & -12.46 & -31.02 \\
\hline Guizhou & 239.93 & 20.35 & 219.58 & 9.33 & 4.67 & 18.57 & -9.23 & -13.90 \\
\hline Yunnan & 455.85 & 45.61 & 410.24 & 17.44 & 8.72 & 30.28 & -12.85 & -21.56 \\
\hline Tibet & 39.59 & 1.76 & 37.83 & 1.61 & 0.80 & 2.00 & -0.39 & -1.20 \\
\hline Shaanxi & 580.39 & 34.64 & 545.75 & 23.19 & 11.60 & 30.67 & -7.48 & -19.08 \\
\hline Gansu & 257.41 & 24.32 & 233.08 & 9.91 & 4.95 & 12.70 & -2.79 & -7.75 \\
\hline Qinghai & 88.05 & 5.47 & 82.58 & 3.51 & 1.75 & 3.63 & -0.12 & -1.88 \\
\hline Ningxia & 80.30 & 6.03 & 74.27 & 3.16 & 1.58 & 5.67 & -2.51 & -4.09 \\
\hline Xinjiang & 393.36 & 28.55 & 364.82 & 15.50 & 7.75 & 21.10 & -5.60 & -13.35 \\
\hline Totals & & & & 881.38 & 440.69 & 1324.19 & -442.81 & -883.50 \\
\hline
\end{tabular}

Sources: China Statistical Yearbook; and authors' calculations. 
No clear pattern clearly emerges from Figure 2. If one ignores the "outliers" of Beijing and Shanghai, which do well because the revenue from the business tax on finance and insurance is protected, the reform seems however to be mildly equalizing as middle-income provinces do a little worse on average than lower-income ones. However, on its own, this is not a reform that would win much support among provinces.

Figure 2. Provincial Losses from Extension of VAT to Services, Base Scenario

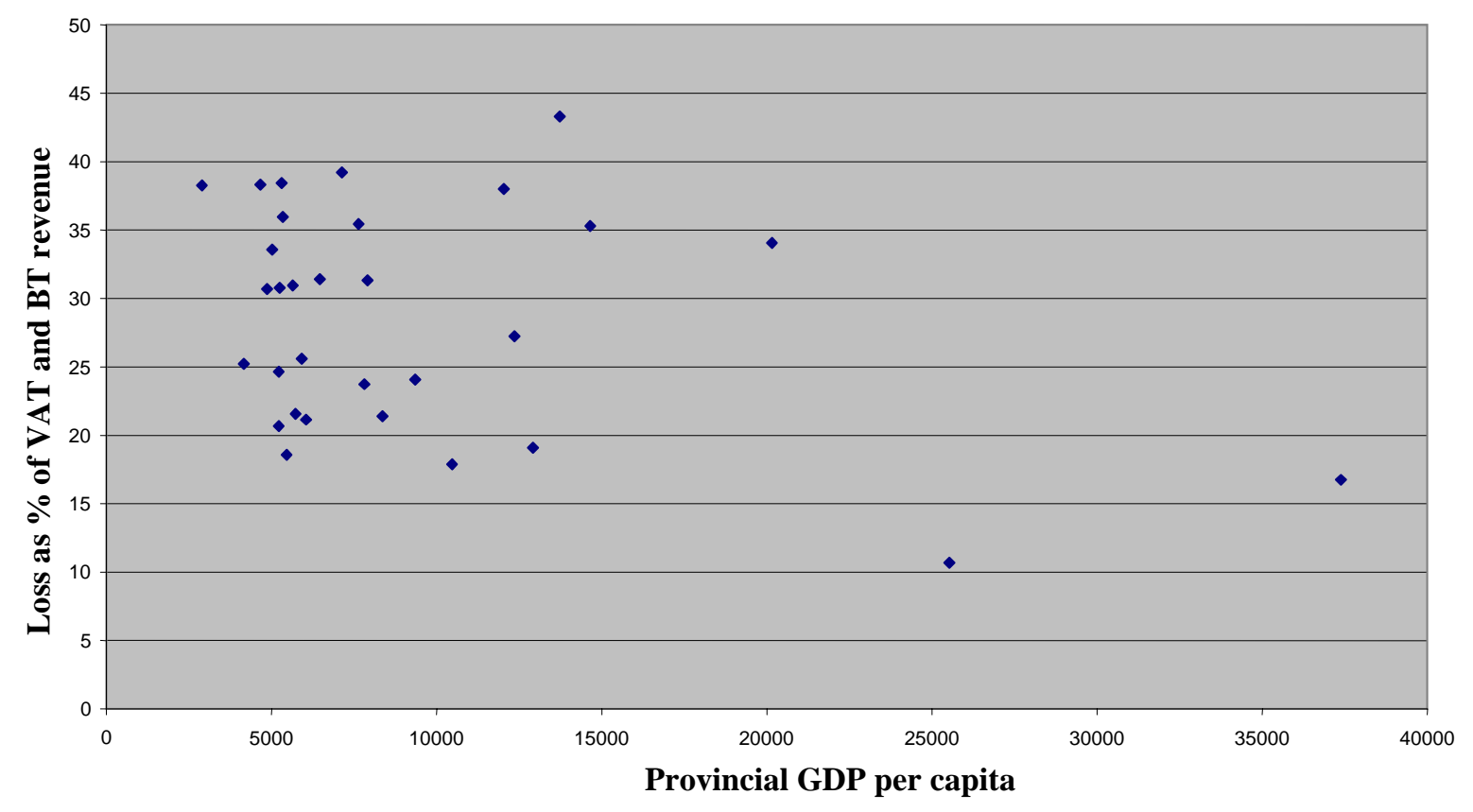

Note: The figure assumes 50 percent collection efficiency.

Sources: China Statistical Yearbook; and and authors’ calculations.

On the other hand, the central government gains considerably from the reform. Given that central government gets 75 percent of VAT, it gets three times the additional revenue from the VAT services accruing to the provinces (i.e., three times between Y 44 billion and Y 88 billion, or Y 132 billion and Y 264 billion). Thus, the center has the capacity of redistributing the additional sums to provinces for equalization, or even increasing the revenue share in favour of local governments. The latter option is discussed next.

\section{Revised sharing rule scenario}

As previously with the C-VAT reform, we could increase the VAT sharing rate from 25 percent to make the reform revenue-neutral for provinces in the aggregate. The sharing rate that does this is the share of post-reform VAT revenue that makes overall (i.e., national) tax revenue from VAT and the business tax equal to revenue from VAT and the business tax in 2001. This new share is approximately 0.30 if the VAT is collected very efficiently 
(100 percent) and 0.37 if the VAT is collected less efficiently (50 percent). Given these new sharing rules, one can calculate the gains and losses from this revenue-neutral (for the provinces) reform. This is given in Table 6 below.

The first column in Table 6 provides 2001 revenue from the VAT and business tax by province. The second and third columns give total revenue from VAT under the new reform, where the new sharing rule has been applied to the new VAT base to make the reform revenue-neutral. Columns 4 and 5 give the monetary gains or losses from this revenueneutral reform, given the two extreme assumptions about efficiency. Columns 6 and 7 give these same gains and losses in percentage form. As before, it is not clear that the benefits or losses fall predominantly on poorer or richer provinces and an increase in the general sharing rule would not appropriately target the provinces facing a revenue shortfall.

\section{THE REVENUE-RETURNED SYSTEM}

In addition to the direct sharing of VAT revenue, the revenue-returned formula (RR) returns an additional portion of VAT and consumption tax revenues to provinces. According to this mechanism, 30 percent of the increase in VAT and consumption tax collection over their 1994 base is returned to the originating province. Viewed as elements of the transfer system, both of these are regressive as they both tend to benefit richer provinces. We discuss here features of the revenue-returned formula and its interactions with the tax VAT reforms discussed in Sections II and III.

\section{The dynamics of RR}

First, our analysis suggests that the revenue-returned formula does not operate uniformly across provinces. Suppose that both province A and province B receive an additional 1 million yuan in VAT or consumption tax revenue. The amount passed back to province A will generally be different to that passed back to province B via the revenue-returned formula. This would not be a problem if this feature had been designed into the formula in a rational way, with the clear objective of helping poorer provinces, or those with the greatest gap between expenditure needs and revenue capacity. However, this is not the case and the differences in treatment of the provinces seem largely arbitrary.

The revenue-returned formula written out in full, states that:

$$
R R_{i, t}=R R_{i, t-1}\left[1+0.3\left(\frac{V A T_{i, t}-V A T_{i, t-1}+C T_{i, t}-C T_{i, t-1}}{V A T_{i, t-1}+C T_{i, t-1}}\right)\right]
$$

where:

$R R_{i, t}$ - revenue-returned to province i at year $\mathrm{t}$

$V A T_{i, t}$ - VAT revenue collected in province $\mathrm{i}$ at year $\mathrm{t}$

$C T_{i, t}$ - CT revenue collected in province i at year $\mathrm{t}$ 
Table 6. Extension of VAT to Services,

(In hundreds of millions of yuan)

\begin{tabular}{|c|c|c|c|c|c|c|c|}
\hline Province & $\begin{array}{c}\text { Current } \\
\text { Revenue } \\
\text { from VAT } \\
\text { and Business } \\
\text { Tax }\end{array}$ & $\begin{array}{l}\text { Post-Reform Revenue } \\
\text { from VAT and Business } \\
\text { Tax (100 percent } \\
\text { efficiency) }\end{array}$ & $\begin{array}{l}\text { Post-Reform } \\
\text { Revenue from } \\
\text { VAT and } \\
\text { Business Tax } \\
\text { (50 percent } \\
\text { efficiency) }\end{array}$ & $\begin{array}{l}\text { Gain from } \\
\text { Reform } \\
\text { (100 percent } \\
\text { efficiency) }\end{array}$ & $\begin{array}{l}\text { Gain from } \\
\text { Reform } \\
\text { (50 percent } \\
\text { efficiency) }\end{array}$ & $\begin{array}{c}\text { Gain from Reform } \\
\text { (100 percent efficiency), } \\
\text { as Percent of Initial } \\
\text { VAT and BT Revenue }\end{array}$ & $\begin{array}{l}\text { Gain from Reform } \\
\text { (50 percent } \\
\text { efficiency), as Percent } \\
\text { of Initial VAT and BT } \\
\text { Revenue }\end{array}$ \\
\hline Beijing & 240.34 & 247.82 & 251.53 & 7.48 & 11.18 & 3.11 & 4.65 \\
\hline Tianjin & 77.87 & 70.96 & 73.12 & -6.91 & -4.75 & -8.87 & -6.10 \\
\hline Hebei & 98.87 & 117.09 & 112.44 & 18.22 & 13.57 & 18.43 & 13.73 \\
\hline $\begin{array}{l}\text { Shanxi } \\
\text { Inner }\end{array}$ & 56.98 & 62.99 & 65.40 & 6.01 & 8.42 & 10.54 & 14.78 \\
\hline Mongolia & 34.45 & 36.64 & 34.55 & 2.19 & 0.10 & 6.34 & 0.29 \\
\hline Liaoning & 154.37 & 133.74 & 137.45 & -20.63 & -16.91 & -13.36 & -10.96 \\
\hline Jilin & 52.23 & 49.52 & 49.61 & -2.71 & -2.63 & -5.20 & -5.03 \\
\hline Heilongjiang & 88.86 & 96.39 & 100.06 & 7.52 & 11.19 & 8.46 & 12.60 \\
\hline Shanghai & 303.07 & 303.72 & 318.12 & 0.65 & 15.05 & 0.21 & 4.97 \\
\hline Jiangsu & 241.48 & 274.21 & 279.47 & 32.74 & 37.99 & 13.56 & 15.73 \\
\hline Zhejiang & 227.30 & 198.31 & 208.75 & -28.99 & -18.56 & -12.75 & -8.16 \\
\hline Anhui & 60.93 & 68.82 & 66.05 & 7.90 & 5.13 & 12.96 & 8.42 \\
\hline Fujian & 102.20 & 109.13 & 104.02 & 6.94 & 1.83 & 6.79 & 1.79 \\
\hline Jiangxi & 43.85 & 54.84 & 49.22 & 10.99 & 5.37 & 25.07 & 12.25 \\
\hline Shandong & 192.98 & 227.93 & 225.74 & 34.94 & 32.75 & 18.11 & 16.97 \\
\hline Henan & 97.25 & 111.97 & 105.26 & 14.73 & 8.01 & 15.14 & 8.24 \\
\hline Hubei & 81.81 & 89.52 & 87.79 & 7.71 & 5.98 & 9.43 & 7.31 \\
\hline Hunan & 65.82 & 80.10 & 74.39 & 14.28 & 8.57 & 21.70 & 13.02 \\
\hline Guangdong & 490.64 & 383.32 & 388.77 & -107.32 & -101.87 & -21.87 & -20.76 \\
\hline Guangxi & 56.74 & 52.66 & 51.40 & -4.07 & -5.33 & -7.18 & -9.40 \\
\hline Hainan & 16.26 & 13.92 & 12.81 & -2.34 & -3.45 & -14.38 & -21.21 \\
\hline Chongqing & 45.60 & 46.08 & 44.21 & 0.48 & -1.39 & 1.05 & -3.05 \\
\hline Sichuan & 100.82 & 103.33 & 97.84 & 2.51 & -2.98 & 2.49 & -2.96 \\
\hline Guizhou & 36.34 & 31.80 & 31.82 & -4.53 & -4.52 & -12.48 & -12.43 \\
\hline Yunnan & 70.30 & 67.62 & 69.72 & -2.68 & -0.58 & -3.81 & -0.82 \\
\hline Tibet & 3.11 & 3.21 & 2.73 & 0.10 & -0.38 & 3.14 & -12.09 \\
\hline Shaanxi & 56.83 & 58.62 & 55.07 & 1.79 & -1.76 & 3.15 & -3.10 \\
\hline Gansu & 30.72 & 32.57 & 32.06 & 1.84 & 1.34 & 6.00 & 4.36 \\
\hline Qinghai & 8.72 & 10.06 & 9.62 & 1.34 & 0.90 & 15.40 & 10.32 \\
\hline Ningxia & 11.37 & 10.26 & 9.98 & -1.11 & -1.40 & -9.80 & -12.28 \\
\hline Xinjiang & 42.64 & 43.59 & 41.75 & 0.95 & -0.89 & 2.23 & -2.09 \\
\hline Totals & $3,190.76$ & $3,190.76$ & $3,190.76$ & 0.00 & 0.00 & & \\
\hline
\end{tabular}

Sources: China Statistical Yearbook; and authors' calculations. 
That is, this year's revenue-returned is equal to last year's, times last year's return times 0.3 times the growth rate of the sum of VAT and consumption tax revenues for that province. As stated here, the formula tracks actual revenue-returned quite well in the recent past, as Table 7 indicates.

Table 7. Returned-Revenue, 1996-2001

(In billions of yuan)

\begin{tabular}{|c|c|c|c|c|c|c|}
\hline & 1996 & 1997 & 1998 & 1999 & 2000 & 2001 \\
\hline Excises & 62.0 & 67.4 & 81.5 & 82.0 & 85.729 & 92.946 \\
\hline VAT & 296.3 & 327.9 & 362.8 & 387.8 & 455.251 & 535.622 \\
\hline Total collection & 358.3 & 395.3 & 444.3 & 469.9 & 541.0 & 628.6 \\
\hline RR actual & 194.9 & 201.2 & 208.3 & 216.73 & 228.2 & 234 \\
\hline RR formula & & 200.9 & 208.7 & 211.9 & 226.6 & 239.3 \\
\hline \multicolumn{7}{|c|}{ In percent of total collection } \\
\hline RR formula & & 50.8 & 47.0 & 45.1 & 41.9 & 38.1 \\
\hline RR actual & & 50.9 & 46.9 & 46.1 & 42.2 & 37.2 \\
\hline
\end{tabular}

Sources: Ministry of finance; and authors’ estimates.

From (1), an increment $\Delta$ in either VAT or consumption tax revenue in year $t$ will lead to the following change in revenue-returned to province $\mathrm{i}$ in that year:

$$
\Delta R R_{i, t}=0.3 \frac{R R_{i, t-1}}{V A T_{i, t-1}+C T_{i, t-1}} \Delta
$$

From (2), it is clear that the share of any increase in VAT or consumption tax revenue in the current year $t$ returned to the province via the revenue-returned formula is simply

$$
0.3 \frac{R R_{i, t-1}}{V A T_{i, t-1}+C T_{i, t-1}}
$$


We call this the incremental tax share. ${ }^{13}$ From equation (3) it is clear that this incremental tax share may in principle differ across provinces. In particular, a province's share will be higher (i) the higher last year's revenue-returned; (ii) the lower last year's VAT and consumption taxes collected.

In practice, one may enquire as to how important are these differences? We do not have all the data to compute these incremental tax shares exactly for a given year, but have enough information to reasonably approximate them. These calculations are given below in Table 8, for the year 2001 using formula (3). While the provincial revenues from VAT are available for 2000, the provincial distribution of aggregate revenue-returned is based on 1998 datathe most recent date for which these data were available-scaled up by the growth in actual revenue-returned. The distribution of consumption tax revenues collected by provinces is also inferred on the basis of VAT collection. In spite of these approximations, the picture is reasonably clear. There is considerable variation with an incremental tax share of only about 8 percent in Heilongjiang, but about 28 percent returned in Yunnan.

How does the revenue return system compare to the simple sharing of VAT and consumption tax revenues? A major disadvantage of the revenue-returned formula relative to simple sharing is that it is not transparent. In particular, the differences across regions are driven by past history and not necessarily by the current or revenue capacities' needs or revenue capacities of provinces. In fact, as shown in Figure 3 below, the sharing rates are mildly equalizing, in that some richer regions tend to get smaller shares, although this tendency is not uniform.

Nevertheless, the revenue-returned formula does have a potentially significant advantage over a sharing rule. Viewed as a transfer, a simple sharing rule is permanently disequalizing, in that richer provinces, which generate more tax revenues, will always get more revenuereturned to them than poor provinces. On the other hand, the revenue-returned formula is only temporarily disequalizing. In the long run, the revenue-returned as a proportion of tax revenue will tend to zero. This is clear from formula (1), because revenue-returned only grows a third as fast as VAT and consumption tax revenue.

The extent of this advantage depends on how fast tax revenues grow. For example, suppose that all tax revenues are growing at 10 percent a year (not an unreasonable assumption for China). Then it would take over a decade for revenue-returned to become half as important for tax revenue as it was in 2001. More generally, if all taxes are growing at some common rate g, we have in Table 9 the "half-life" of the formula. Thus, it would take decades for the $\mathrm{RR}$ to fall by half should revenue growth slow down. The advantage of the revenue-retuned formula as declining over time should therefore not be oversold.

\footnotetext{
${ }^{13}$ Of course, when the VAT share of 25 percent is included, a province receives 25 percent plus the incremental tax share.
} 
Table 8. Incremental Tax Shares by Region, 2001

\begin{tabular}{|c|c|c|c|c|}
\hline Region & $\begin{array}{l}\text { Revenue-returned, } \\
20001 / \\
(1)\end{array}$ & $\begin{array}{l}\text { Total VAT Collected, } \\
2000 \\
(2)\end{array}$ & $\begin{array}{c}\text { Total Consumption } \\
\text { Tax Collected, } \\
20002 / \\
(3)\end{array}$ & $\begin{array}{c}\text { Incremental Share, } \\
20013 /\end{array}$ \\
\hline & & (In billions of yuan) & & (In percent) \\
\hline Beijing & 8.37 & 18.38 & 3.45 & 11.50 \\
\hline Tianjin & 5.16 & 10.45 & 1.96 & 12.48 \\
\hline Hebei & 9.05 & 17.48 & 3.28 & 13.08 \\
\hline Shanxi & 4.72 & 10.21 & 1.92 & 11.67 \\
\hline Inner Mongolia & 3.43 & 5.35 & 1.01 & 16.16 \\
\hline Liaoning & 13.16 & 22.68 & 4.26 & 14.65 \\
\hline Jilin & 5.14 & 8.16 & 1.53 & 15.91 \\
\hline Heilongjiang & 6.36 & 18.45 & 3.47 & 8.70 \\
\hline Shanghai & 18.48 & 37.42 & 7.03 & 12.47 \\
\hline Jiangsu & 17.15 & 43.46 & 8.17 & 9.97 \\
\hline Zhejiang & 12.93 & 36.01 & 6.77 & 9.07 \\
\hline Anhui & 6.02 & 10.50 & 1.97 & 14.48 \\
\hline Fujian & 6.30 & 14.14 & 2.66 & 11.25 \\
\hline Jiangxi & 3.68 & 6.03 & 1.13 & 15.42 \\
\hline Shandong & 13.17 & 35.88 & 6.74 & 9.27 \\
\hline Henan & 9.56 & 16.90 & 3.18 & 14.29 \\
\hline Hubei & 8.12 & 13.51 & 2.54 & 15.18 \\
\hline Hunan & 8.49 & 10.44 & 1.96 & 20.53 \\
\hline Guangdong & 20.06 & 52.85 & 9.93 & 9.59 \\
\hline Guangxi & 5.57 & 8.26 & 1.55 & 17.03 \\
\hline Hainan & 0.69 & 1.14 & 0.21 & 15.35 \\
\hline Sichuan & 8.35 & 13.54 & 2.54 & 15.59 \\
\hline Chongqing & 3.61 & 5.91 & 1.11 & 15.44 \\
\hline Guizhou & 4.00 & 4.87 & 0.92 & 20.74 \\
\hline Yunnan & 14.17 & 12.55 & 2.36 & 28.51 \\
\hline Tibet & 0.19 & 0.32 & 0.06 & 15.43 \\
\hline Shaanxi & 4.29 & 7.60 & 1.43 & 14.26 \\
\hline Gansu & 4.27 & 4.78 & 0.90 & 22.54 \\
\hline Qinghai & 0.71 & 1.19 & 0.22 & 14.96 \\
\hline Ningxia & 0.72 & 1.42 & 0.27 & 12.76 \\
\hline Xinjiang & 2.29 & 6.11 & 1.15 & 9.47 \\
\hline Totals & 228.20 & 455.99 & 85.70 & \\
\hline Average & & & & 14.44 \\
\hline
\end{tabular}

Sources: China Statistical Yearbook; and and authors’ calculations.

1/ Provincial shares of total based on 1998 data.

2/ Provincial shares of aggregate consumption tax collected assumed the same as for VAT.

3 / Incremental tax share $=0.3$ times column 1 divided by Column 2 and Column 3. 
Table 9. The "Half-Life" of the Revenue-Returned Formula

\begin{tabular}{cc}
\hline Growth Rate of Rax Revenues, $g$ & $\begin{array}{c}\text { Number of Years for Revenue-returned as a Proportion of Tax } \\
\text { Revenue to Fall by Half }\end{array}$ \\
\hline 0.05 & 20.45 \\
0.10 & 10.54 \\
0.15 & 7.24 \\
\hline
\end{tabular}

Source: Authors’ calculations.

Figure 3. Incremental VAT Shares by Province 1/

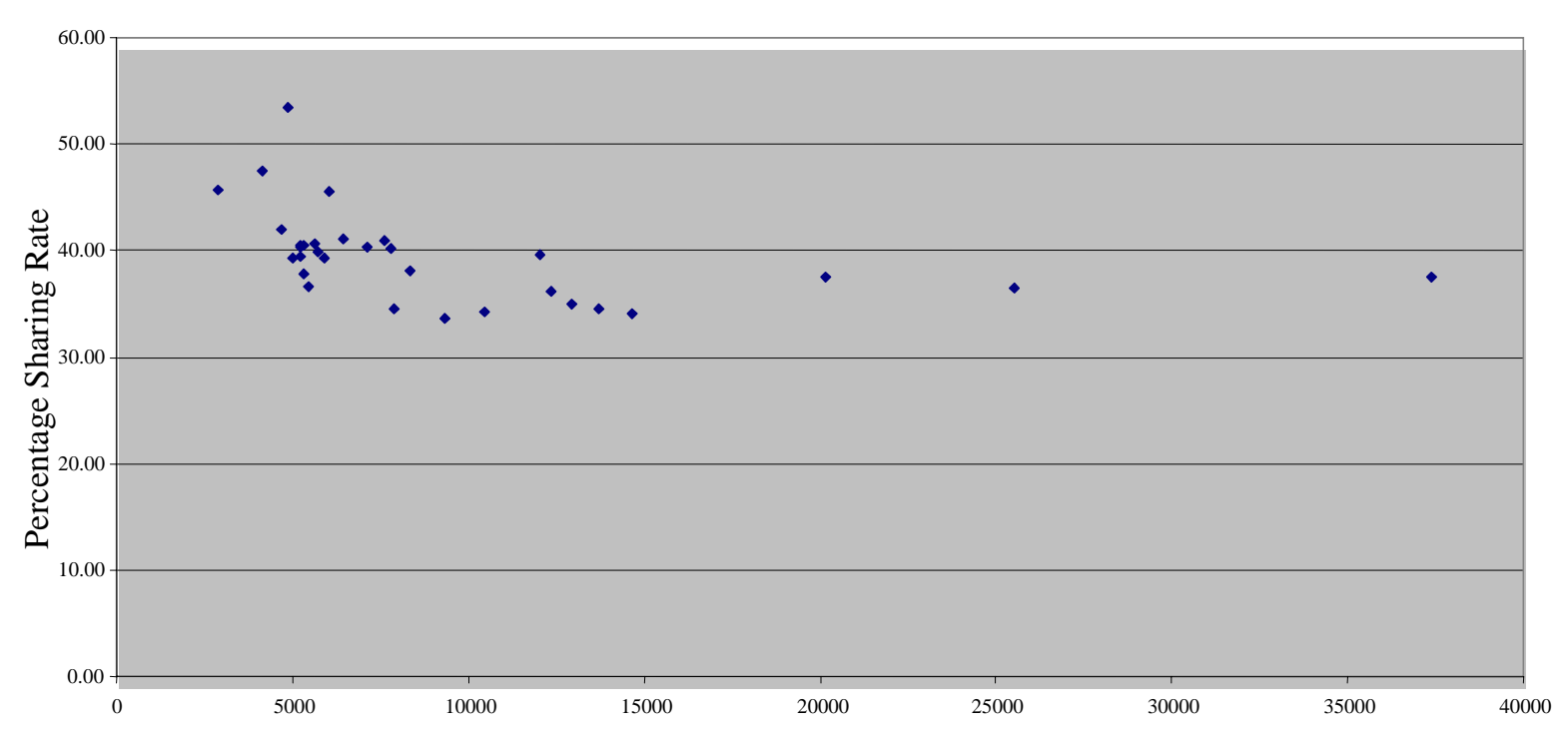

1/ Includes 25 percent VAT share.

Source: Authors’ calculations.

\section{Including $R R$ in the C-VAT reform}

The simulations presented in Section II on the introduction of the C-VAT ignored the operation of the revenue-returned formula. It is in fact, quite difficult to incorporate the effect of this formula, as it seems to be applied asymmetrically. The formula is generally only applied in the case it leads to an overall increase the revenue-returned to a province relative to the previous year. As the move to a C-VAT would clearly reduce revenue, two possibilities could be considered: 
1. No change in revenue-returned. If the C-VAT reform takes place in a period of weaker economic growth so that VAT revenue and consumption tax revenue together show negative growth when the reform is taken into account, then the "overall increase" constraint is binding.

2. Change in revenue-returned. If the C-VAT reform takes place in a period of strong economic growth so that VAT revenue and consumption tax revenue together show positive growth in spite of the reform, then the "overall increase" constraint is not binding.

If the first scenario holds, the losses already calculated apply - there is no need for further calculation, as the decrease in VAT leads to no decrease in revenue-returned. In the second scenario, we need also to calculate the additional losses to the provinces arising from the reduction in revenue-returned.

These calculations are given in Table 10 below. The first three columns of this table are identical to those in Table 1. Instead of applying the 25 percent sharing rule to column three to calculate the loss of VAT revenue, we apply 25 percent plus the incremental tax shares of Table 8. This captures the fact that when the VAT base falls, there is a fall in revenuereturned. The loss of VAT revenue can again be expressed in percentage terms, which is done in the last column of the table. For illustrative purpose, we have only considered here the case of 50 percent collection efficiency. On average, the percentage losses are up by about 5 percentage points, from an average of 15.40 percent to 20.07 percent.

Figure 4. Provincial Revenue Losses from C-VAT Reform, Allowing for Revenue-Returned

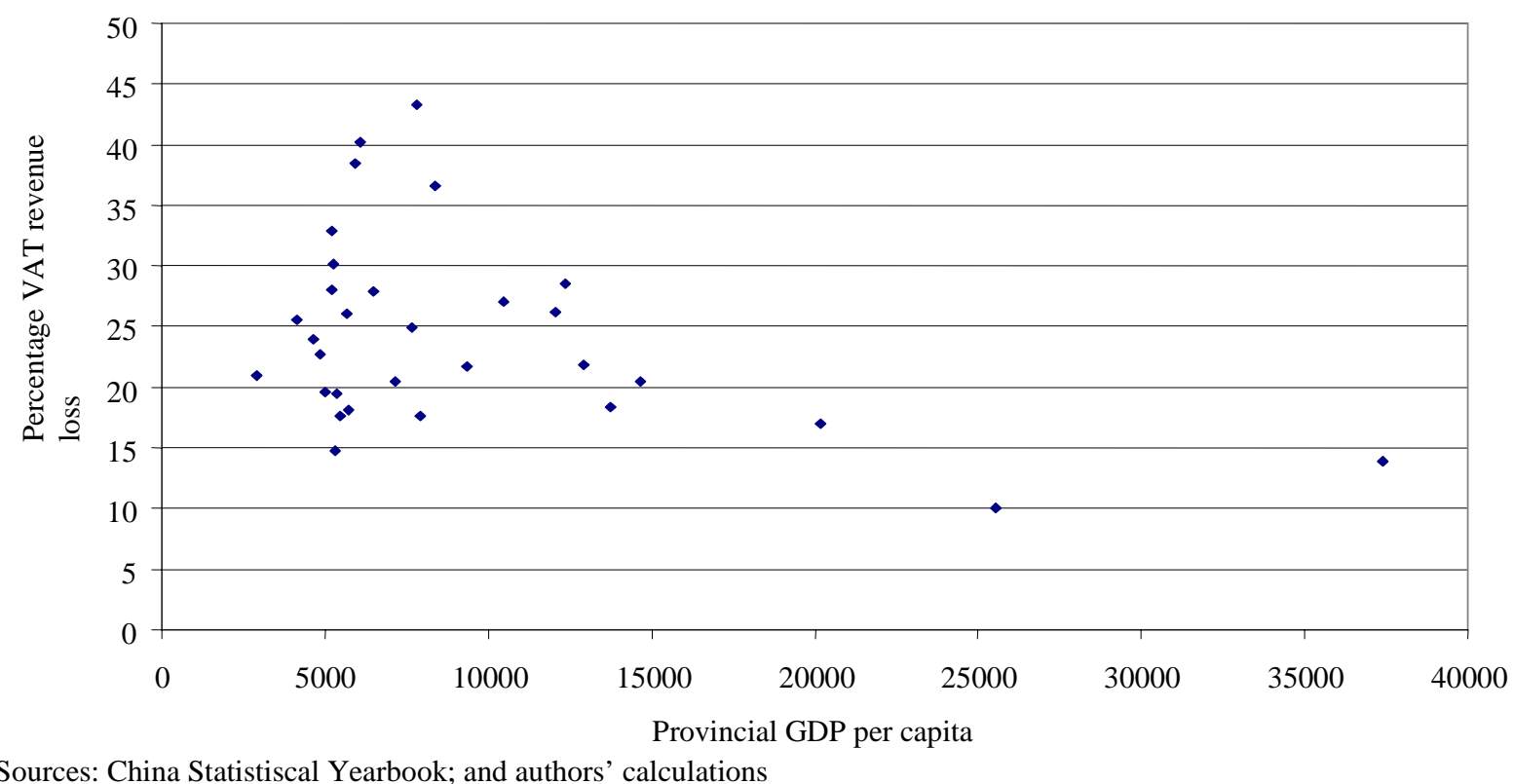

Sources: China Statistiscal Yearbook; and authors’ calculations 
Would the inclusion of the revenue-returned formula change the distribution of losses across provinces? Figure 4 shows that with the revenue-returned there is a more pronounced inverted "U" shape relationship between percentage losses and per capita income of provinces than in the simple base scenario. Extending our analysis to include the RR formula would thus only reinforce the conclusions of Section II.

Table 10. C-VAT Reform Base Scenario Allowing for Revenue-Returned (In hundreds of millions of yuan)

\begin{tabular}{|c|c|c|c|c|c|c|c|}
\hline Region & $\begin{array}{c}2001 \\
\text { Value of } \\
\text { Wholesale, } \\
\text { Retail and } \\
\text { Catering } \\
\text { Trade } \\
\end{array}$ & $\begin{array}{c}2001 \\
\text { Value of } \\
\text { Secondary } \\
\text { Industry } \\
\text { (excluding } \\
\text { construction) } \\
\end{array}$ & $\begin{array}{l}\text { Calculated } \\
\text { Purchases } \\
\text { of M\&E }\end{array}$ & $\begin{array}{c}\text { Incremental } \\
\text { Tax Shares }\end{array}$ & $\begin{array}{l}\text { Loss of } \\
\text { VAT } \\
\text { Revenue } \\
\text { (50 percent } \\
\text { CE) }\end{array}$ & $\begin{array}{c}\text { 2001VAT } \\
\text { Revenue }\end{array}$ & $\begin{array}{l}\text { Revenue Loss } \\
\text { as Percent of } \\
\text { Initial VAT } \\
\text { Revenue } \\
\text { (50 percent } \\
\text { CE) } \\
\end{array}$ \\
\hline Beijing & 23.78 & 81.62 & 19.03 & 36.50 & 0.59 & 5.90 & 10.01 \\
\hline Tianjin & 17.83 & 82.12 & 18.64 & 37.48 & 0.59 & 3.49 & 17.03 \\
\hline Hebei & 50.17 & 243.96 & 55.15 & 38.08 & 1.78 & 4.88 & 36.54 \\
\hline Shanxi & 14.60 & 77.98 & 17.51 & 36.67 & 0.55 & 3.09 & 17.68 \\
\hline Inner Mongolia & 14.82 & 50.67 & 11.82 & 41.16 & 0.41 & 1.48 & 27.87 \\
\hline Liaoning & 69.65 & 219.01 & 51.55 & 39.65 & 1.74 & 6.65 & 26.12 \\
\hline Jilin & 26.74 & 72.47 & 17.37 & 40.91 & 0.60 & 2.42 & 24.95 \\
\hline Heilongjiang & 35.02 & 176.78 & 39.85 & 33.70 & 1.14 & 5.26 & 21.72 \\
\hline Shanghai & 55.04 & 212.12 & 48.90 & 37.47 & 1.56 & 11.20 & 13.91 \\
\hline Jiangsu & 95.51 & 427.09 & 97.19 & 34.97 & 2.89 & 13.20 & 21.88 \\
\hline Zhejiang & 90.88 & 310.63 & 72.46 & 34.07 & 2.10 & 10.24 & 20.49 \\
\hline Anhui & 34.08 & 119.16 & 27.73 & 39.48 & 0.93 & 2.83 & 32.91 \\
\hline Fujian & 41.15 & 164.53 & 37.80 & 36.25 & 1.16 & 4.08 & 28.56 \\
\hline Jiangxi & 19.21 & 59.56 & 14.04 & 40.42 & 0.48 & 1.72 & 27.99 \\
\hline Shandong & 89.13 & 409.22 & 92.93 & 34.27 & 2.71 & 10.03 & 26.99 \\
\hline Henan & 42.21 & 227.99 & 51.15 & 39.29 & 1.71 & 4.44 & 38.51 \\
\hline Hubei & 47.34 & 206.65 & 47.12 & 40.18 & 1.61 & 3.71 & 43.34 \\
\hline Hunan & 38.24 & 130.95 & 30.54 & 45.53 & 1.18 & 2.94 & 40.23 \\
\hline Guangdong & 104.44 & 473.24 & 107.58 & 34.59 & 3.16 & 17.25 & 18.34 \\
\hline Guangxi & 29.52 & 64.82 & 16.00 & 42.03 & 0.57 & 2.39 & 23.95 \\
\hline Hainan & 7.26 & 7.16 & 2.10 & 40.35 & 0.07 & 0.35 & 20.46 \\
\hline Chongqing & 16.78 & 57.66 & 13.44 & 40.59 & 0.46 & 1.78 & 26.11 \\
\hline Sichuan & 47.48 & 140.78 & 33.36 & 40.44 & 1.15 & 3.80 & 30.17 \\
\hline Guizhou & 8.41 & 33.50 & 7.70 & 45.74 & 0.30 & 1.43 & 20.99 \\
\hline Yunnan & 20.22 & 72.40 & 16.81 & 53.51 & 0.76 & 3.36 & 22.74 \\
\hline Tibet & 1.66 & 1.08 & 0.36 & 40.43 & 0.01 & 0.08 & 14.74 \\
\hline Shaanxi & 12.47 & 60.61 & 13.70 & 39.26 & 0.46 & 2.33 & 19.60 \\
\hline Gansu & 12.30 & 35.65 & 8.47 & 47.54 & 0.34 & 1.34 & 25.60 \\
\hline Qinghai & 2.31 & 8.92 & 2.06 & 39.96 & 0.07 & 0.39 & 18.14 \\
\hline Ningxia & 2.35 & 10.22 & 2.33 & 37.76 & 0.07 & 0.39 & 19.42 \\
\hline Xinjiang & 12.82 & 45.00 & 10.47 & 34.47 & 0.31 & 1.74 & 17.64 \\
\hline Totals & & & & & 31.48 & 134.17 & \\
\hline Averages & & & & & & & 24.34 \\
\hline
\end{tabular}

Sources: China Statistical Yearbook; and authors’ calculations. 


\section{Conclusions ANd Policy Options}

This paper illustrates that reforming indirect taxation would generate considerable revenue losses for local governments. The move to a C-VAT would exclude capital goods from the tax base, and also generate losses for the central government. Extending the coverage of the VAT to services would lead to substantial revenue gains to the center, but would imply the elimination of the business tax on most services, an important source of revenue for local governments. In the absence of any compensatory mechanism, there would therefore be little chance that these reforms would be carried out.

A second objective of this paper is to study the distributional impact of the revenue-retuned grant formula. Although technically part of the transfer system, rather than a tax, the revenue-returned interacts with indirect taxes as it is specifically designed to reallocate centrally collected tax revenues back to the provinces. We find that the revenue-returned formula is not transparent and differentiates between regions in an arbitrary way. Second, while it is designed to grow less rapidly than VAT and consumption tax revenue, it may take decades for it to really shrink in importance, especially if economic growth slows. In contrast, simple sharing of VAT revenue is transparent and uniform across regions. However, it has the disadvantage that it is permanently disequalizing.

This paper discusses several options for compensation. However, it turns out that the reforms considered here do not affect all the provinces uniformly. The move to a C-VAT for instance would particularly affect provinces where industry represents a large share of their economic activity. Poorer provinces, where agriculture is still predominant, and richer provinces, where services have taken a growing role, would be less affected.

Compensating the provinces for their revenue shortfall by changing some parameters of the current system would thus not be effective. In the case of a move to a C-VAT, local governments could be compensated by either a larger share in the VAT revenue sharing or by increasing the standard VAT rate. However, both changes would not adequately target the provinces facing a revenue shortfall and would add to the regressivity of the current system: wealthier provinces generate more VAT revenue per capita and would receive the largest share of the compensation. Including, if the revenue-returned mechanism in the analysis does not change the results.

A more drastic move away from the current system may be called for. Such an option could be to extend the equalization grants introduced in 1994. The 1994 fiscal reforms correctly designed an equalization transfer system, based on expenditure needs and revenue capacities. However, the resources subsequently available to the system were inadequate to make any significant equalization impact. In such a mechanism, any change in the capacity of a province to mobilize revenue would be picked up in the formula and the amount of transfers modified accordingly. A more targeted compensation system could hence be provided, 
adequately compensating the provinces facing a revenue shortfall stemming from a tax reform. ${ }^{14}$

This redesigned transfer system would have the potential to achieve more effective redistribution, but it could probably not do so in isolation. Other measures would be needed to convince richer provinces to renounce their revenue-returned and accept a more redistributive system. Such a comprehensive reform package would include a joint reassessment of expenditure responsibilities together with revamped revenue assignments, as well as more transparent access to capital markets

Currently, almost all tax rates and bases are nationally set, even for those taxes from which the revenue goes entirely to local governments. Tax reforms are needed to provide provinces and counties with some control over rates of assigned taxes at the margin. This is a key element of fiscal accountability. The choice of taxes, where some local control is envisaged, should be such as not to lead to excessive economic distortions and tax competition.

There are strong arguments for standardizing the base for the personal income tax. However, bounded control over a number of percentage points for provinces (piggybacking) should provide them with much greater room for maneuver than at present. Such reforms will also provide significant revenues to the more advanced coastal provinces, thereby reducing the political pressures for returning revenue. More extensive use of property taxes at the countylevel, including enhanced valuation and recording mechanisms for leasehold properties, and basing annual taxes on the annual lease value equivalent should also be considered.

On the spending side, sub-national expenditure assignments are incommensurate with their available resources. Even some middle-income counties face difficulties in meeting pension liabilities, and unfunded mandates from the center continue to pose difficulties, including for key priority issues such as basic education or health care. The recentralization of pension liabilities and unemployment insurance should be considered.

The reforms described above form part of an extensive and interlocking package of measures that will take several years to implement fully. China clearly cannot move on all these fronts simultaneously and rapidly. While the pace of the reforms may be gradual, the scope should be comprehensive. The design of the ultimate overall reform package should be consistent, and it will be important to keep this medium-term goal in sight.

\footnotetext{
${ }^{14}$ This option is discussed in much greater detail in Ahmad, Singh, and Fortuna (2004).
} 


\section{REFERENCES}

Ahmad, Ehtisham, Gao Qiang, and Vito Tanzi, 1995, Reforming China's Public Finances, (Washington, International Monetary Fund).

Ahmad, Ehtisham, Raju Singh, and Mario Fortuna, 2004, “Toward More Effective Redistribution: Reform Options for Intergovernmental Transfers in China,” IMF Working Paper, WP/04/98 (Washington: International Monetary Fund)

Ebrill, Liam, M. Keen, J.P. Bodin, and V. Summers, 2001, The Modern VAT (Washington: International Monetary Fund). 